\title{
SIGURNOST I ZAŠTITA PRI UNIŠTAVANJU VOJNIH EKSPLOZIVNIH SREDSTAVA
}

UDK 623.365:331.45

PRIMLJENO: 7.4.2016.

PRIHVAĆENO: 29.8 .2016$.

\begin{abstract}
SAŽETAK: Vojna eksplozivna sredstva (pješačko, topničko i raketno streljivo, protupješačke, protuoklopne i minobacačke mine, zrakoplovno i mornaričko streljivo, eksplozivi, bombe, itd.) su predmeti punjeni eksplozivnim tvarima (inicijalni i brizantni eksplozivi, baruti, pirotehničke smjese) razvrstana u klasu 1, potklase 1.1. do 1.6. skupine opasnosti, opasnih tvari. Imajući u vidu konstrukcijske, kemijske, fizičke i druge značajke eksplozivnih sredstava uvijek se moraju poduzimati sve propisane mjere sigurnosti i zaštite počevši za vrijeme njihove proizvodnje, zatim tijekom procesa skladištenja, čuvanja, održavanja, rukovanja i prijevoza, pa do njihove uporabe ili uništavanja.

Vojna eksplozivna sredstva koja iz bilo kojih razloga ne mogu biti dalje u uporabi te su otpisana kao dotrajala, neispravna, opasna za ljudske živote i okoliš ili nepotrebna korisniku, uništavaju se, odnosno dovode u stanje trajne i potpune neopasnosti i neškodljivosti za ljudski život i okoliš. Uništavaju se i eksplozivna sredstva koja nisu eksplodirala nakon uporabe, kao i eksplozivna sredstva u sklopu razminiranja minskih polja zaostalih nakon rata, na propisan način uz poduzimanje svih mjera sigurnosti i zaštite izvršitelja, ostalih sudionika i okoliša.
\end{abstract}

Ključne riječi: vojna eksplozivna sredstva, eksplozivne tvari, razminiranje, uništavanje eksplozivnih sredstava

\section{UVOD}

Najčešći uzroci nesreća s opasnim tvarima u miru su ljudska greška ili propusti u radu, nestručno rukovanje, nedostatak ili nestručno napisani propisi i postupci u određenim situacijama, neredovito praćenje kakvoće roba, nedostatak suvremene opreme, alata i uređaja, nedovoljna stručna osposobljenost radnika, navika, itd.

Vojna eksplozivna sredstva (u daljnjem tekstu „eksplozivna sredstva“) su razvrstana u klasi 1 opasnih roba, a prema karakteru, učinku i po-

*Mr. sc. Đorđi Todorovski, dipl. ing., (dordi.todorovski@gmail. com), Veleučilište u Karlovcu, Trg J. J. Strossmayera 9, 47000 Karlovac, Ilija Uvalić, struč. spec. ing. sec., JVP Grada Siska, Vatrogasna 1, 44000 Sisak, (ilijauvalic@gmail.com). sljedicama djelovanja na cilju pripadaju skupini tvarno-tehničkih sredstava kojih eksploatacija, za razliku od drugih tvarno-tehničkih sredstava, traje tek nekoliko sekunda, jer su ona samo izvršni element oružanog sustava i upotrebljavaju se za najneposrednije uništavanje žive sile i drugoga vojnoga neprijateljskog potencijala.

Zbog ubrzana rasta potrošnje u ratu, u miru se stvara velika pričuva eksplozivnih sredstava i ista čuva u namjenski izgrađenim objektima. Tijekom skladištenja i čuvanja eksplozivna sredstva prirodno stare i mijenjaju početnu kakvoću. Pritom parametri početne kakvoće, koji su postignuti u proizvodnji, opadaju s vremenom skladištenja, odnosno čuvanja i u svezi s klimatskim, odnosno mikroklimatskim uvjetima čuvanja. Promjena kakvoće ogleda se u promjeni fizikal- 
no-kemijskih, mehaničkih i balističkih svojstava, zbog čega se provode povremeni nadzori kakvoće i propisani procesi održavanja. Ako se tijekom provjere kakvoće utvrdi da eksplozivna sredstva nisu za daljnju uporabu zbog neispravnosti, isteka roka uporabe, ako su opasna za okolicu, ako se proglase neperspektivnima za oružane snage, ako je remont nerentabilan ili nemoguć, ona se otpisuju.

Otpisana eksplozivna sredstva koja su opasna za daljnje čuvanje i koja se ne mogu upotrijebiti uništavaju određene postrojbe i stručne ekipe pirotehničari tehničke struke na propisan način, strogo postupajući prema Elaboratu i tehnološkom postupku, na odobrenom mjestu - uništavalištu eksplozivnih sredstava.

Poseban i iznimno značajan problem predstavljaju zaostala minska polja i neeksplodirana eksplozivna sredstva iz Domovinskog rata. Uništavanje ovih eksplozivnih sredstava je specifično glede uništavanja otpisanih eksplozivnih sredstava. Od izvršitelja uništavanja ovih eksplozivnih sredstava zahtijeva se konstantno ispunjavanje i posebnih mjera sigurnosti i zaštite koje se posebice odnose na način rada kao i na uporabu specijalne opreme i uređaja za rad na siguran način.

\section{DEFINIRANJE KORIŠTENIH POJMOVA}

Opasne tvari - su tvari koje na razne načine i u različitim situacijama mogu ugroziti život i zdravlje ljudi, materijalna dobra i okoliš na manjoj ili većoj udaljenosti od mjesta gdje se nalaze.

Eksplozivne tvari (inicijalni $i$ brizantni eksplozivi, baruti, pirotehničke smjese) - su tvari koje služe za: izbacivanje projektila iz cijevi pješačkog ili topničkog naoružanja, pokretanje (pogon) raznih raketnih sustava, iniciranje drugih eksplozivnih tvari, te rasprskavanje košuljice projektila ili osiguranje nekog drugog efekta na cilju. To je takav sustav, relativno nestabilan, koji je sposoban pod utjecajem vanjskog djelovanja (početni impuls - udar, trenje, toplina) prijeći (u termodinamičkom smislu) u stabilniji sustav, pri čemu obavlja golem rad u stvaranju plinovitih produkata zagrijanih na nekoliko tisuća stupnjeva i pod tlakom od $2 * 10^{10} \mathrm{~Pa}$ (Pleše, 2008.).

Eksplozivna sredstva (pješačko, topničko i raketno streljivo, protupješačke, protuoklopne $i$ minobacačke mine, zrakoplovno i mornaričko streljivo, eksplozivi, bombe, itd.) - su predmeti punjeni eksplozivnim tvarima razvrstana u klasu 1, potklase 1.1. do 1.6. skupine opasnosti, i 13 (trinaest) skupina spojivosti (A, B, C, D, E, F, G, $H, J, K, L, N, S)$ opasnih tvari. Imajući u vidu konstrukcijske, kemijske, fizičke i druge značajke eksplozivnih sredstava uvijek se moraju poduzimati sve propisane mjere sigurnosti i zaštite, počevši za vrijeme njihove proizvodnje, zatim tijekom procesa skladištenja, čuvanja, održavanja, rukovanja i prevoženja, pa sve do njihove uporabe ili uništavanja (AASTP-3, 1995.).

\section{UNIŠTAVANJE VOJNIH EKSPLOZIVNIH SREDSTAVA I EKSPLOZIVNIH TVARI}

\section{Opće odredbe}

Na specifičan i posebno propisan način uništavaju se:

- eksplozivna sredstva i eksplozivne tvari koje iz bilo kojih razloga ne mogu biti dalje u uporabi te su otpisane kao dotrajale neispravne ili nepotrebne korisniku

- eksplozivna sredstva i eksplozivne tvari koje su iz bilo kojih razloga dospjele u takvo stanje da neposredno ili potencijalno, a posebice pri uporabi ili nakon nje, objektivno znače opasnost za ljudske živote i okoliš

- eksplozivna sredstva i eksplozivne tvari za koje se utvrdi da se procesom delaboracije, remonta ili na drugi način ne mogu dovesti u stanje potpune ili djelomične uporabljivosti ili je njihovo dovođenje $u$ ispravno i neopasno stanje neracionalno i gospodarski neopravdano 
- eksplozivna sredstva koja nisu eksplodirala nakon bojevog gađanja ili su zaostala nakon rata

- eksplozivna sredstva u sklopu razminiranja minskih polja zaostalih nakon rata, dezaktiviranja mina iznenađenja, kada se to ne može izvesti na drugi, ali potpuno siguran način.

Eksplozivna sredstva mogu se uništiti na više načina, a način uništavanja odabire se ovisno o:

- vrsti i količini eksplozivnih sredstava za uništavanje

- tehničkom stanju eksplozivnih sredstava za uništavanje (stupanj opasnosti pri određenom načinu uništavanja, stanje kompletnosti, uzroci zbog kojih se uništavaju)

- položaju i okolnostima u kojima se eksplozivna sredstva nalaze u trenutku kad se moraju uništiti

- mogućnostima i isplativosti uništavanja eksplozivnih sredstava.

Postupak uništavanja eksplozivnih sredstava je složen i veoma odgovoran proces, s nesagledivo neželjenim posljedicama ako je obavljen nestručno i nepravilno, ako je odabran neprimjeren način uništavanja i ako pritom nisu poduzete sve odgovarajuće sigurnosne mjere i mjere zaštite na radu. Ta složenost ne proizlazi toliko iz samoga tehnološkog postupka uništavanja koliko iz velikog broja i opsega pripremnih mjera koje se u cijelosti i na vrijeme moraju predvidjeti, planirati i osigurati prije uništavanja, za vrijeme i nakon uništavanja u danim okolnostima i mogućnostima. Neželjene posljedice nepravilna rada pri uništavanju mogu se javiti u fazi pripreme, za vrijeme radova, neposredno nakon toga (što je najčešće) i nakon duljeg vremena, odnosno nakon niza godina.

Sve vrste eksplozivnih sredstava i eksplozivnih tvari mogu se uništavati:

- detonacijom u fugasama (topnički projektili, mine za minobacač i ručni bacač, protupješačke i protuoklopne mine, ručne bombe, topničke kapsule, eksploziv, riječne i morske mine, raketno gorivo mase veće od $10 \mathrm{~kg}$, veće količine pješačkog streljiva)
- detonacijom na licu mjesta pojedinačno u slučajevima zatajenja projektila nakon gađanja ili zaostalih iza rata, kao i mina u minskom polju pri deminiranju

- spaljivanjem (malodimni baruti na otvorenu prostoru, pješačko streljivo u posebnom kotlu), uz uvjet da se ono ne pretvori u detonaciju, što se postiže tehnologijom izvedbe i ograničavanjem količine eksplozivnog materijala koji se na taj način želi uništiti

- potapanjem u vodu ili odgovarajuću tekućinu (posebna eksplozivna sredstva, dimna ili kemijska), i to prema posebnom tehnološkom postupku

- na ekološki potpuno prihvatljiv način, veće količine otpisanih eksplozivnih sredstava i eksplozivnih tvari - demilitarizacijom.

Ako je razlog uništavanja čišćenje zemljišta od neeksplodiranih eksplozivnih sredstava ili zaostalih minsko-eksplozivnih sredstava, primjenjuje se posebna metoda pretraživanja i poseban način uništavanja. Tu zadaću trebaju skupa obavljati stručno osposobljene i kvalitetno opremljene ekipe pirotehničara i deminera.

Ovisno o količini eksplozivnih sredstava koja se uništava, njihovu općem stanju i mogućnosti prijevoza te stanju kompletnosti, eksplozivna sredstva i eksplozivne tvari mogu se uništavati detonacijom, i to na:

- stalnim mjestima za uništavanje

- privremenim mjestima za uništavanje

- slučajnim mjestima za uništavanje.

Svaki od ovih načina uništavanja ima specifičnosti u pogledu organizacije rada i sigurnosnih mjera te u samom postupku po fazama rada.

\section{Uništavanje eksplozivnih sredstava na stalnim mjestima za uništavanje}

Stalno mjesto za uništavanje zemljišta je određene veličine $(500 \times 500 \mathrm{~m})$ koje mora biti udaljeno od naselja najmanje $2500 \mathrm{~m}$. Uži prostor mora biti označen i osiguran za vrijeme uni- 
štavanja eksplozivnih sredstava te imati uređeno sklonište za ljude na najmanje $200 \mathrm{~m}$ i zaklon za palitelja na $150 \mathrm{~m}$ od fugasa, zaklone za ljude koji su u osiguranju poligona i zaklon za čuvanje dnevne potrebe sredstava za aktiviranje na udaljenosti najmanje $200 \mathrm{~m}$ od fugasa i najmanje $50 \mathrm{~m}$ od skloništa i zaklona za ljude. Svi zakloni i skloništa moraju biti propisno pokriveni.

\section{Uništavanje eksplozivnih sredstava detonacijom na stalnim mjestima za uništavanje}

Skupno uništavanje eksplozivnih sredstava detonacijom na stalnim mjestima za uništavanje ima sljedeće faze:

- prethodna priprema

- priprema užeg prostora za uništavanje, iskopavanje jama - fugasa

- doprema eksplozivnih sredstava do mjesta za uništavanje

- slaganje eksplozivnih sredstava u fugase

- osiguranje i pregled užeg i šireg prostora poligona za uništavanje

- priprema sredstava za paljenje fugasa

- priprema neposredno prije uništavanja

- uništavanje - paljenje fugasa

- postupak nakon paljenja fugasa.

\section{Prethodna priprema}

Prethodna priprema za skupno uništavanje eksplozivnih sredstava obuhvaća: pismeno izvješće lokalnim tijelima vlasti, zapovijed za uništavanje, ovjerovljen predmet otpisa eksplozivnih sredstava, dijelova eksplozivnih sredstava ili sirovina, izradu plana rada, plana tvarne pripreme za uništavanje, izdvajanje potrebnih sredstava za uništavanje, pripremu ljudstva i sredstava za uništavanje eksplozivnih sredstava.

Priprema užeg prostora za uništavanje, iskopavanje jama - fugasa

Priprema užeg prostora za uništavanje obuhvaća iskopavanje jama - fugasa - dubina 80 - $100 \mathrm{~cm}$, najviše 30-50 kg neto mase čistog eksploziva istodobno za uništavanje u jednoj fugasi, širina i dužina u skladu s vrstom i količinom eksplozivnih sredstava, za jedno ispucavanje najviše šest fugasa koje su međusobno udaljene od 10 do $20 \mathrm{~m}$.

Doprema eksplozivnih sredstava do mjesta za uništavanje

Doprema eksplozivnih sredstava do mjesta za uništavanje obuhvaća poduzimanje posebnih sigurnosnih mjera ovisno o stanju eksplozivnih sredstava, prijevoz ljudstva za rad u posebnim vozilima, osiguranje alata, a prema potrebi i strojeva za kopanje fugasa

\section{Slaganje eksplozivnih sredstava u fugase}

Na dno se slažu eksplozivna sredstva s debljom košuljicom i manjom količinom eksploziva u projektilu, a na vrh fugase stavlja se eksploziv koji će dati dovoljno snažan impuls za detoniranje čitavog sadržaja fugase; eksplozivna sredstva u fugasi slažu se u obliku stošca tako da međusobno prianjaju najtanjim dijelom košuljice; međuprostori se lagano popunjuju upaljačima i ručnim bombama; tijekom slaganja u fugasu na eksplozivnim sredstvima ne smije se stajati nogama; nakon slaganja fugasa se lagano zatvara pažljivim nasipavanjem sloja po sloja iskopane zemlje, a ostavlja se slobodan prostor za postavljanje eksplozivnog naboja za uništavanje.

\section{Osiguranje i pregled užeg i šireg prostora} - poligona za uništavanje

Osiguranje i pregled užeg i šireg prostora poligona za uništavanje - stražom se zatvaraju svi putovi koji vode k mjestu za uništavanje, postavljaju se ploče "Opasno za život! Zabranjen prilaz!"; broj stražarskih mjesta ovisi o konfiguraciji zemljišta; dogovaraju se signali za početak i prestanak paljenja fugasa te za povlačenje ljudstva s osiguranja; pregledava se zemljište - uže i šire od slučajnog nailaska nepozvanih osoba ili stoke.

\section{Priprema sredstava za paljenje fugasa}

Priprema sredstava za paljenje fugasa - sporogorućeg stijenja, detonatorskih kapsula, elek- 
tričnih detonatorskih kapsula, uređaja za električno paljenje, kopča za dezaktiviranje fugasa (slika 1.), eksploziva, alata za izradu upaljača, ljepljivih vrpca, uređaja za provjeru ispravnosti električnih detonatorskih kapsula i minerske žice, alata za zatrpavanje fugasa.

Žica se vezuje za kopču neposredno prije postavljanja detonatorske kapsule na sporogorući stijenj.

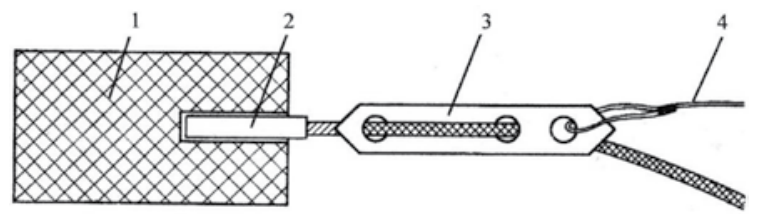

1 - eksplozivni naboj; 2 - detonatorska kapsula; 3 - kopča; 4 žica za povlačenje

Slika 1. Kopča za dezaktiviranje fugasa

Figure 1. Clasp for deactivating the fugas

Eksplozivni naboj kompletira, povezuje sustav za paljenje i pali profesionalni pirotehničar, a ne pomoćno ljudstvo koje je bilo angažirano u kopanju fugasa.

\section{Priprema neposredno prije uništavanja}

Pripreme za paljenje fugasa sporogorućim stijenjem obuhvaćaju ove radnje:

- provlačenje okomito odsječena kraja sporogorućeg stijenja kroz kopču za dezaktiviranje za $5 \mathrm{~cm}$, koliko je potrebno za uvlačenje i pričvršćivanje detonatorske kapsule

- kad se svi elementi pripreme i međusobno povežu, postavljaju se u fugase

- eksplozivni metak za rušenje (TNT od 200 g) postavlja se na eksplozivni naboj za uništavanje koji je na vrhu naslagane fugase, a pritom se pazi na nalijeganje eksploziva i postavljanje eksploziva s kapsulom u ležište (prethodno treba očistiti ležište od zemlje, a zatim ga lagano učvrstiti ručnim nasipavanjem sitne zemlje)

- fugasa se potpuno zatrpava (prvo pažljivo rukama, a zatim se lopatom nanosi sloj po sloj zemlje bez kamenja)
- provjerava se položaj eksplozivnog metka, za pločicu se kroz određen otvor vezuje prethodno postavljena žica za potezanje, a tek se onda zatrpava taj dio fugase; pritom treba paziti na to da se žica ne povuče.

Pripreme za paljenje fugasa detonirajućim i sporogorućim stijenjem te detonatorskom kapsulom broj 8 obuhvaćaju ove radnje:

- prema broju fugasa odsijeca se određen broj detonirajućih stjenjeva dužine koja odgovara udaljenosti do mjesta na kojem se postavlja sporogorući stijenj s detonatorskom kapsulom

- krajevi detonirajućih stjenjeva povezuju se oko detonatorske kapsule sa sporogorućim stijenjem

- krajevi detonirajućih stjenjeva prema fugasama se kompletiraju detonatorskim kapsulama

- detonatorske kapsule koje su kraj fugasa bile spojene s detonirajućim stijenjem postavljaju se u ležišta eksplozivnih metaka svake fugase

- kopče za dezaktiviranje se ne postavljaju, dalje se postupa kao u prethodnom slučaju

- u slučaju prekida i neaktiviranja neke fugase ostaje se u zaklonu i čeka najmanje deset minuta, a zatim se ide do mjesta paljenja kako bi se utvrdilo jesu li svi detonirajući stjenjevi detonirali. Ako koji od njih nije prihvatio detonaciju, fugasa se dezaktivira

- mjesto za paljenje sporogorućeg stijenja od zaklona je udaljeno 10 - $20 \mathrm{~m}$, ovisno o pogodnosti zemljišta, zbog utvrđivanja jesu li svi detonirajući stjenjevi detonirali.

Pripreme za paljenje fugasa električnom detonatorskom kapsulom obuhvaćaju ove radnje:

- ispitivanje električnih detonatorskih kapsula, električnoga kabela i stroja za paljenje neposredno prije uništavanja

- stroj se za paljenje osigurava da ga ne može upotrijebiti nitko osim voditelja radova 
- električne kapsule povezuju se u skladu s planiranom shemom, vodeći računa o udaljenostima između fugasa

- kapsule se postavljaju u ležišta eksplozivnih metaka (TNT 200 g) svake fugase, lagano se utvrđuju, a potom se fugase zatrpavaju

- svi spojevi električne mreže podižu se sa zemlje tako da pri paljenju struja ne otječe u zemlju, jer bi to prouzrokovalo zatajenje mreže (neaktiviranje)

- krajeve kabela u zaklonu povezuje voditelj radova sa strojem za paljenje tek pred samo paljenje, kad su obavljene sve pripreme, dobiveno izvješće od stražara da je sve u redu te pregledano zemljište oko fugasa dalekozorom i očevidom.

\section{Uništavanje - paljenje fugasa}

Postupak paljenja fugasa pri uništavanju eksplozivnih sredstava stijenjskim paljenjem je sljedeći:

- određuje se onoliko osoba za paljenje koliko ima fugasa

- na dani znak upravitelja radova određene osobe pokraj fugasa pripaljuju sporogorući stijenj

- na dani znak ljudstvo iz osiguranja i ostalo ljudstvo koje je slobodno ide u sklonište

- nakon paljenja fugasa svi idu u zaklon; ako se koja fugasa ne može pripaliti, osoba koja to nije uspjela, mora skupa s ostalima otići u sklonište

- prije ulaska u sklonište upravitelj radova još jedanput provjerava zemljište oko fugasa i ako primijeti nepozvane osobe, odmah osobno dezaktivira sve fugase potezanjem žice

- kada se nakon dezaktiviranja uklone razlozi zbog kojih je to učinjeno, fugase se ponovno pripremaju za paljenje na opisan način

- nakon odbrojavanja detonacija ljudstvo ne izlazi iz skloništa najmanje deset minuta
- ako sve fugase nisu uništene, upravitelj radova dezaktivira onu fugasu koja nije djelovala snažnim potezanjem svake žice pojedinačno

- ako se nije pripalila koja fugasa, upravitelj to treba učiniti deset minuta nakon detonacije ostalih fugasa: promotri zemljište, a zatim se vraća u zaklon.

Eksplozivni naboj kompletira, povezuje sustav za paljenje i pali profesionalni pirotehničar, a ne pomoćno ljudstvo koje je bilo angažirano u kopanju i slaganju fugasa.

Postupak paljenja fugasa pri uništavanju električnim paljenjem je sljedeći:

- upravitelj zapovijeda ljudstvu da ode u zaklon jer je električni kabel povezan s vodičima krajnjih detonatorskih električnih kapsula, sve kapsule međusobno povezane i ostatak električnoga kabela unesen u zaklon za paljenje fugasa

- dogovorenim signalom upravitelj radova daje znak da svi odu u sklonište

- $\quad$ kad se upravitelj radova uvjeri da su svi u skloništu i da nema neočekivanih osoba u opasnom pojasu fugasa, ulazi u zaklon za paljenje, spaja kabele sa strojem za paljenje, izlazi iz zaklona, ponovno promatra opasno zemljište oko fugasa i, kada je siguran da je sve u redu, aktivira stroj na propisan način, čime izaziva detonaciju fugasa (projektila - eksplozivnih sredstava)

- deset minuta nakon paljenja upravitelj izlazi iz zaklona, ide do fugasa i provjerava jesu li i kako detonirale.

\section{Postupak nakon paljenja fugasa}

Postupak nakon jednog paljenja razlikuje se od postupka nakon uništavanja određenog dana te od svekolikog uništavanja po istoj zapovijedi od nekoliko dana.

Nakon svakog paljenja zemljište se pretražuje 50 m od fugasa, a na kraju radnog dana 300 $350 \mathrm{~m}$ od fugasa kako bi se pronašla nedetonirana eksplozivna sredstva. Ljudima koji pretražuju 
zemljište nije dopušteno dirati odbačene dijelove eksplozivnih sredstava. Oni samo označuju mjesto i zovu pirotehničara - upravitelja radova.

Ako je moguće, pirotehničar prikuplja odbačene dijelove, pravi posebnu fugasu i uništava ih povećanom količinom eksploziva. Ako je pomicanje odbačenih dijelova opasno, uništavaju se na licu mjesta. Zabranjeno je zakopavati nedetonirana ili nepotpuno detonirana eksplozivna sredstva u zemlju ili ih bacati u grmlje, vrtače, jame, ponore bez obzira na stupanj opasnosti od tih ostataka.

\section{Uništavanje eksplozivnih sredstava spaljivanjem na stalnim mjestima za uništavanje}

Uništavanje eksplozivnih sredstava spaljivanjem razumijeva njihovo izvrgavanje povišenoj temperaturi na kojoj se ona pretvaraju u proizvode izgaranja s krutim ostacima i kovnim dijelovima ili bez njih.

Za taj način uništavanja iskorištava se svojstvo većeg broja eksplozivnih sredstava i eksplozivnih tvari da na otvorenu prostoru i uz određene uvjete razmjerno mirno izgaraju i da ne nastupi detonacija.

Inicijalni eksplozivi ne mogu se uništavati spaljivanjem (osim u posebnim slučajevima uz prethodno ovlaživanje) jer na povišenoj temperaturi odmah prelaze u detonaciju. Zbog toga se ni detonatorske kapsule ne mogu uništavati spaljivanjem.

Topničke kapsule i pješačko streljivo ipak se uništavaju spaljivanjem iako u sastavu imaju i inicijalnu kapsulu koja pri spaljivanju detonira, ali se to događa pojedinačno i količina inicijalne mješavine je veoma mala.

Brizantni eksplozivi također se mogu spaljivati, ali samo u ograničenim količinama, jer bi kod većih količina razmjerno mirno izgaranje prešlo u detonaciju i uzrokovalo neželjene posljedice.

Crni barut ne uništava se spaljivanjem zbog velike brzine i nagla izgaranja, što također može prouzrokovati neželjene posljedice. Crni barut uništava se potapanjem u tekuću vodu, jer se njegove sastavnice pod utjecajem vode lako razlažu. Kalijeva salitra, koja je jedna od sastavnica crnog baruta, otapa se u vodi i dovodi crni barut do brza razlaganja. Jednom ovlažen crni barut gubi svoja obilježja, a sušenjem ga nije moguće poboljšati i ponovno mu vratiti početnu kakvoću.

Eksplozivne tvari koje se mogu uništiti spaljivanjem jesu:

- sve vrste malodimnih baruta, s određenim ograničenjem

- sve vrste brizantnih i gospodarskih eksploziva u određenim količinama i eksplozivnih sredstava punjenih brizantnim eksplozivima kakva su detonirajući stjenjevi

- pješačko streljivo određene vrste, uz neka ograničenja

- sve vrste topničkih kapsula koje se sa čahura mogu skinuti odvijanjem

- sporogorući stijenj

- temeljni barutni naboji za minobacačke i tromblonske mine

- signalni i osvjetljujući sastavi

- dimne tvari i dimna sredstva

- inicijalne kapsule, ali samo kada se nalaze u kapsulama pješačkog streljiva i topničkim kapsulama

- brizantni eksplozivi u granatama, raketnim projektilima i drugim eksplozivnim sredstvima, ali uz posebne uvjete rada

- pogonski raketni naboji koji se ne mogu izvaditi iz svoje komore, odnosno raketnog motora, uz posebne uvjete rada.

\section{Uništavanje eksplozivnih sredstava potapanjem na stalnim mjestima za uništavanje}

Uništavanje eksplozivnih sredstava potapanjem u more na stalnim mjestima za uništavanje veoma je jednostavno, ali se time onečišćuje more i okoliš. Jer, brizantni eksplozivi, posebice trinitrotoluen, ostaju nepromijenjenih svojstava i nakon više od dvije stotine godina stajanja u vodi. Potapanjem u more skupno se uništavaju samo 
posebna eksplozivna sredstva (dimna, zapaljiva, osvjetljujuća i kemijska), i to po posebnom dopuštenju ovlaštenog tijela na mjestima u moru koja su točno određena državnim propisima.

\section{Uništavanje eksplozivnih sredstava na zatečenim mjestima}

Pod zatečenim mjestom za uništavanje razumijeva se razmjerno mali zemljišni prostor (na površini zemlje, pod zemljom, pod vodom, u zidu stambenog ili industrijskog objekta) na kojemu se slučajno zateklo jedno ili više eksplozivnih sredstava, i to:

- kada u bojnom gađanju projektil zataji na cilju

- kada nastane rikošet i projektil zaluta, a ne eksplodira pri padu i zaustavljanju na zemlji ili u zemlji

- kada se pronađe neeksplodirani projektil koji potječe iz rata

- kada se zbog požara, prevrtanja vozila, sudara ili eksplozije pojedina neeksplodirana eksplozivna sredstva ne mogu ukloniti

- kada se naiđe na postavljenu protupješač$\mathrm{ku}$, protuoklopnu ili diverzantsku minu, a nije ju moguće ukloniti na drugi način.

Uništavanje neeksplodiranih eksplozivnih sredstava nakon gađanja veoma je opasan posao i gotovo se uvijek mora obaviti na mjestu nalaženja eksplozivnog sredstva. Ta zadaća ubraja se u specifične radove zbog složenosti postupka uništavanja i posebnih sigurnosnih mjera koje se moraju poduzeti i kojih se svaka osoba koja sudjeluje u uništavanju mora strogo držati u svim fazama rada.

Opasnost pri uništavanju neeksplodiranih projektila proizlazi iz činjenice što je nakon lansiranja projektila djelovanjem inercije i centrifugalne sile upaljač u aktivnom stanju (armiran), odnosno dijelovi su i mehanizmi upaljača dovedeni u potpuno slobodan položaj da u trenutku udara u zapreku (ili slučajnim laganim udarom u njih pri pronalaženju, pomicanju ili uništavanju) projektil lako može detonirati.
Strogo je zabranjeno pomicati ili prevoziti neeksplodirane projektile koji su prošli kroz cijev ili su na bilo koji drugi način bili poslani na cilj (lansirani, bačeni rukom). Iznimka su pojedine vrste zrakoplovnih bomba i raketnih projektila koje se prema ocjeni stručnog povjerenstva mogu dezaktivirati na licu mjesta, a potom bezopasno odnijeti na mjesto pogodno za uništavanje.

S vremenom se na neeksplodiranim i neaktiviranim eksplozivnim sredstvima pojavljuje korozija, nestaju oznake i boja koje govore o vrsti eksplozivnih sredstava. Posebice su tako opasne protupješačke i protuoklopne mine, ručne bombe, kasetne bombice.

Uništavanju neeksplodiranih eksplozivnih sredstava prethodi:

- pronalaženje sredstava ili mjesta gdje je eksplozivno sredstvo palo

- označivanje mjesta i izvješćivanje o nađenom sredstvu

- osiguranje mjesta do uništavanja.

Način pronalaženja i postupak povjerenstva za pronalaženje, obilježivanje i uništavanje eksplozivnog sredstva uređuje se posebnim Pravilnikom za organizaciju i izvedbu gađanja pješačkim, topničkim, raketnim, minobacačkim i drugim oružjem s programima gađanja.

Nakon gađanja povjerenstvo uz pomoć određenog broja vojnika postrojbe koja je gađala, organizira pronalaženje i obilježivanje projektila koji su zatajili.

Kada se naiđe na neeksplodirani projektil, koji može biti na površini zemlje, djelomično ili potpuno u zemlji, obavješćuje se ovlaštena osoba iz povjerenstva kako bi odredila položaj i stanje projektila. Nakon toga se pokraj projektila postavlja kolčić sa zastavicom trokutna oblika kako bi se mjesto obilježilo. Za slučaj kad je projektil pod zemljom, pri određivanju položaja i dubine može se upotrijebiti i metaldetektor (minoistraživač).

Kada se pronađu i obilježe projektili koji su zatajili, upravitelj ostaje s potrebnim brojem pi- 
rotehničara koje osobno odredi zbog uništavanja neeksplodiranih projektila.

Pri uništavanju neeksplodiranih eksplozivnih sredstava zbog velike opasnosti i delikatnosti posla potrebno je stalno imati na umu i sljedeće:

- primjenu svih općih mjera pirotehničke sigurnosti

- primjenu svih posebnih i specifičnih sigurnosnih mjera za svaki slučaj i za svaku vrstu eksplozivnih sredstava

- pripremu i organizaciju mjesta za uništavanje neeksplodiranih eksplozivnih sredstava

- dosljedno poštovanje uputa o uništavanju.

Primjena svih općih mjera pirotehničke sigurnosti obuhvaća:

- potpunu osposobljenost ljudi koji rukuju eksplozivnim sredstvima i obavljaju posao njihovog uništavanja

- strogo poštovanje pravila i propisa koji uređuju rad s eksplozivnim sredstvima, posebice pri uništavanju neeksplodiranih eksplozivnih sredstava

- veliku stegu u radu za vrijeme uništavanja eksplozivnih sredstava

- psihološku stabilnost ljudi

- stalan nadzor, budnost i kontrolu pri realizaciji procesa uništavanja eksplozivnih sredstava

- provjeru sredstava za paljenje pri uništavanju eksplozivnih sredstava

- određivanje sigurnosnih udaljenosti pri uništavanju eksplozivnih sredstava

- određivanje količine eksploziva za uništavanje neeksplodiranog eksplozivnog sredstva

- sklanjanje ljudstva i eksplozivnih tvari u skloništa pri ispucavanju

- primjerenu organizaciju rada na terenu i strogo izvršavanje zapovijedi i naputaka rukovoditelja uništavanja eksplozivnih sredstava

- uređenje zemljišta prije uništavanja i poslije uništavanja eksplozivnih sredstava
- organiziranu protupožarnu, sanitetsku i higijensko-tehničku zaštitu, te zaštitu okoliša pri uništavanju eksplozivnih sredstava.

Primjena svih posebnih i specifičnih sigurnosnih mjera za svaki slučaj i za svaku vrstu eksplozivnih sredstava obuhvaća sljedeće:

- strogo je zabranjen prijevoz ili pomicanje neeksplodiranih eksplozivnih sredstava

- nije dopušteno samostalno obavljanje radnji ako to nije predviđeno ovjerenim dokumentima po kojima se realizira proces uništavanja eksplozivnih sredstava

- nije dopušteno pušenje, samovolja, nedisciplina, ometanje pirotehničara u radu, konzumacija alkohola i narkotika prije, za vrijeme i nakon uništavanja eksplozivnih sredstava

- obvezatno je prepoznati pronađeno neeksplodirano sredstvo i utvrditi stanje

- nije dopušten rad osobama koje se ne osjećaju sposobnima za siguran rad pri uništavanju eksplozivnih sredstava, kao i neovlaštenim osobama

- neeksplodirana eksplozivna sredstva moraju se otkopavati na siguran i točno propisan način, i to onoliko koliko je potrebno da se postavi određena količina eksploziva za aktiviranje

- prije početka uništavanja neeksplodiranih eksplozivnih sredstava potrebno je osigurati zaklone i skloništa za palitelje, ljude iz fizičkog osiguranja mjesta za uništavanje i ostaloga pomoćnog ljudstva

- na krškom i kamenitom tlu mora se sigurnosni pojas povećati i zbog velike opasnosti od razlijetanja dijelova projektila i kamenja

- neeksplodirani projektil i mine u vodi uništavaju se na poseban i specifičan način

- ako je neeksplodirani projektil blizu objekta koji se želi zaštititi od razaranja, onda se gradi nasip i/ili kopa kanal određene dubine, ovisno o konkretnoj situaciji

- na kraju uništavanja neeksplodiranih eksplozivnih sredstava sastavlja se izvješće. 
Obvezno je strogo poštovati upute o uništavanju, a prema potrebi se primjenjuju posebni uređaji koji omogućavaju uništavanje sa sigurne udaljenosti kumulativnim mlazom, roboti, pomoćna sredstva, klinasti topovi.

$\mathrm{Na}$ osnovi vrste neeksplodiranoga eksplozivnog sredstva određuje se količina brizantnog eksploziva trinitrotoluena (TNT) za aktiviranje, izrađuje se eksplozivni naboj i kompletira sustav za paljenje, stijenjski ili električni. U Tablici 1 . (SSNO, 1980.) navedena je količina TNT-a potrebna za uništavanje neeksplodiranih eksplozivnih sredstava ovisno o vrsti.

Kako bi se spriječila mogućnost ranjavanja ili stradavanja pri uništavanju neeksplodiranih eksplozivnih sredstava (palitelja, ljudi iz fizičkog osiguranja, ljudi koji rade na uništavanju eksplozivnih sredstava i pomoćne radne snage), određuje se sigurnosni pojas te grade skloništa od razlijetanja komadića košuljice eksplozivnog sredstva i/ili kamenja. Određivanje sigurnosnih udaljenosti ovisi o kalibru i vrsti eksplozivnog sredstva te o načinu uništavanja eksplozivnih sredstava - pojedinačno ili skupno.

Udaljenosti razlijetanja fragmenata pri eksploziji neeksplodiranog eksplozivnog sredstva ili mina u minskom polju navedene su u Tablici 2 (SSNO, 1980.).
Tablica 1. Količina TNT-a potrebna za uništavanje neeksplodiranih eksplozivnih sredstava

Table 1. Quantity of TNT required for destruction of unexploded explosive devices

\begin{tabular}{|c|c|c|}
\hline $\begin{array}{l}\text { Red. } \\
\text { br. }\end{array}$ & Vrsta eksplozivnog sredstva & $\begin{array}{l}\text { Količina } \\
\text { TNT-a } \\
\text { (kg) }\end{array}$ \\
\hline 1. & $\begin{array}{l}\text { Protupješačke i protuoklopne mine, } \\
\text { mine za ručne bacače, minobacačke } \\
\text { mine, ručne bombe i ostala eksplo- } \\
\text { zivna sredstva s tankom košuljicom }\end{array}$ & 0,2 \\
\hline 2. & $\begin{array}{l}\text { Trenutno-fugasne granate kalibra do } \\
50 \mathrm{~mm}\end{array}$ & 0,2 \\
\hline 3. & $\begin{array}{l}\text { Trenutno-fugasne granate kalibra od } \\
50 \text { do } 100 \mathrm{~mm}\end{array}$ & 0,4 \\
\hline 4. & $\begin{array}{l}\text { Trenutno-fugasne granate kalibra od } \\
100 \text { do } 150 \mathrm{~mm}\end{array}$ & 0,6 \\
\hline 5. & $\begin{array}{l}\text { Trenutno-fugasne granate kalibra od } \\
150 \text { do } 200 \mathrm{~mm}\end{array}$ & $0,6-1,0$ \\
\hline 6. & $\begin{array}{l}\text { Trenutno-fugasne granate kalibra } \\
\text { većeg od } 200 \mathrm{~mm}\end{array}$ & $1,0-2,0$ \\
\hline 7. & $\begin{array}{l}\text { Pancirna zrna s eksplozivnim nabo- } \\
\text { jem kalibra do } 75 \mathrm{~mm}\end{array}$ & 1,0 \\
\hline 8. & $\begin{array}{l}\text { Pancirna zrna s eksplozivnim nabo- } \\
\text { jem kalibra većega od } 75 \mathrm{~mm}\end{array}$ & $1,0-2,0$ \\
\hline 9. & $\begin{array}{l}\text { Eksplozivna glava s eksplozivnim } \\
\text { nabojem raketnih projektila }\end{array}$ & $0,6-1,0$ \\
\hline 10. & Kumulativni projektili & $0,2-0,4$ \\
\hline
\end{tabular}


Tablica 2. Udaljenosti razlijetanja fragmenata pri eksploziji neeksplodiranog eksplozivnog sredstva

Table 2. Fragment dispersal distances in the explosion of an unexploded explosive device

\begin{tabular}{|c|l|c|c||}
\hline \multirow{2}{*}{$\begin{array}{c}\text { Red. } \\
\text { br. }\end{array}$} & \multicolumn{1}{|c|}{ Vrsta eksplozivnog sredstva } & \multicolumn{2}{c|}{$\begin{array}{c}\text { Udaljenost razlijetanja fragmenata eksplozivnih } \\
\text { sredstava (m) }\end{array}$} \\
\cline { 2 - 4 } & \multicolumn{1}{|c}{$\begin{array}{c}\text { pri detonaciji na } \\
\text { površini }\end{array}$} & pri detonaciji u fugasi \\
\hline 1. & $\begin{array}{l}\text { Ručne bombe, mine za ručne bacače, tromblonske mine, RPG, } \\
\text { protupješačke mine }\end{array}$ & 100 & 200 \\
\hline 2. & Topnički projektili kalibra do $76 \mathrm{~mm}$ & 500 & 250 \\
\hline 3. & Topnički projektili kalibra od 76 do $105 \mathrm{~mm}$ & 600 & 300 \\
\hline 4. & Topnički projektili kalibra od 105 do $122 \mathrm{~mm}$ & 800 & 400 \\
\hline 5. & Topnički projektili kalibra od $122 \mathrm{do} 155 \mathrm{~mm}$ & 1.200 & 600 \\
\hline 6. & Topnički projektili kalibra većeg od $155 \mathrm{~mm}$ & 1.500 & 750 \\
\hline 7. & Zrakoplovne bombe mase do $500 \mathrm{~kg}$ & 2.000 & 1.000 \\
\hline 8. & Zrakoplovne bombe mase veće od $500 \mathrm{~kg}$ & 2.500 & 1.250 \\
\hline
\end{tabular}

\section{RAD NA UNIŠTAVANJU NEEKSPLODIRANOG EKSPLOZIVNOG SREDSTVA}

Rad stručno osposobljenih djelatnika - pirotehničara nakon pronalaska neeksplodiranih eksplozivnih granata ili mina u minskom polju i njihova zadaća na uništavanju tih sredstva temelji se na:

- potvrđivanju opasnosti koju predstavljaju pronađena neeksplodirana eksplozivna sredstva

- provođenju sigurnosnih i zaštitnih mjera pri uništavanju pronađenih neeksplodiranih eksplozivnih sredstava

- pomoći nadležnih tijela u realizaciji uništavanja pronađenih neeksplodiranih eksplozivnih sredstava

- provedbi postupka uništavanja pronađenih neeksplodiranih eksplozivnih sredstava.

\section{Potvrđivanje opasnosti koju predstavlja neeksplodirano eksplozivno sredstvo}

Za potvrđivanje opasnosti koju predstavlja neeksplodirano eksplozivno sredstvo potrebno je provesti:

- identifikaciju vrste eksplozivnog sredstva i upaljača, odnosno kakav je njihov status

- procjenu stanja eksplozivnog sredstva kad identifikacija nije moguća
- novu procjenu opasnosti eksplozivnog sredstva na temelju dodatnih informacija

- upoznavanje nadležnog tijela o opasnostima eksplozivnog sredstva kada to nadilazi stručnost djelatnika na konkretnoj zadaći

- promjenu operativnog tempa rada i prioriteta kada se za to pojavi potreba, uz prethodno odobrenje nadležnog tijela

- korištenje svih poznatih izvora informacija o vrstama eksplozivnih sredstava

- precizno opisivanje mogućih učinaka eksplozivnog sredstva na bliži i daljnji okoliš

- propisane organizacijske procedure pri uništavanju eksplozivnog sredstva

- dostavljanje izvješća nadležnom tijelu o svim mogućim opasnostima eksplozivnog sredstva.

\section{Provođenje sigurnosnih i zaštitnih mjera pri uništavanju neeksplodiranog eksplozivnog sredstva}

Za provođenje sigurnosnih i zaštitnih mjera pri uništavanju pronađenog neeksplodiranog eksplozivnog sredstva potrebno je znati sljedeće:

- Koje su zaštitne mjere potrebne u skladu s opasnošću?

- Kako se izrađuje plan provedbe u skladu s operativnim zahtjevima i organizacijskim procedurama? 
- Koja su sredstva dostupna za provedbu zaštitnih mjera i koje su njihove sposobnosti?

- Koje dokumente i ljude je potrebno konzultirati kako bi se točno utvrdilo koje su mjere potrebne?

- Koje su veze s ostalim agencijama i pojedincima zbog savjetovanja u cilju osiguranja provedbe zaštitnih mjera?

- Koji je mogući učinak zaštitnih mjera na okolinu?

- Kako ocijeniti učinkovitost plana uništavanja eksplozivnih sredstava?

- Kako planirati i provoditi evakuaciju?

- Koja je minimalna sigurna udaljenost za različite opasnosti?

- Kada i zašto se može promijeniti minimalna sigurnosna udaljenost?

\section{ZAKLJUČAK}

1. Uništavanje eksplozivnih sredstava je proces kojim se otpisana i planirana eksplozivna sredstva, mine u minskom polju i neeksplodirane granate nakon uporabe, detonacijom, običnim izgaranjem ili na drugi način dovode u stanje trajne i potpune neopasnosti i neškodljivosti za ljudski život i okoliš.

2. Postupak uništavanja eksplozivnih sredstava je složen i veoma odgovoran proces, s nesagledivo neželjenim posljedicama ako je obavljen nestručno i nepravilno, ako je odabran neprimjeren način uništavanja i ako pritom nisu poduzete sve odgovarajuće sigurnosne mjere i mjere zaštite na radu.

3. Uništavanje neeksplodiranih eksplozivnih sredstava nakon gađanja ili zaostala nakon rata (granate, mine u minskom polju) veoma je opasan posao i gotovo se uvijek mora obaviti na mjestu nalaženja. Ova zadaća ulazi u specifične radove zbog složenosti postupka uništavanja i posebnih sigurnosnih mjera koje se moraju poduzeti i kojih se svaka osoba koja sudjeluje u uništavanju mora strogo držati u svim fazama rada.

4. Rad stručno osposobljenih pirotehničara nakon pronalaska neeksplodiranih eksplozivnih granata ili mina u minskom polju temelji se na: potvrđivanju opasnosti koju predstavljaju ta sredstva, provođenju sigurnosnih i zaštitnih mjera pri njihovom uništavanju, pomoći od nadležnih tijela pri provedbi njihovog uništavanja i provedbi kompletnog postupka njihovog uništavanja.

\section{LITERATURA}

AASTP-3, Manual of NATO Safety Principles for the Hazard Classification of Military Ammunition and Explosives, 1995.

Pleše, M.: Fizika i kemija eksplozivnih tvari, MORH, Zagreb, 2008., 20-21.

SSNO: Municija TSI-I/1, knjiga I, deo I, Split, 1974.

SSNO: Municija TS/-I/3, knjiga I, deo II, Split, 1974.

SSNO: Uništavanje municije, MES i drugih eksplozivnih materijala $T U-V, 9$, uputstvo, Beograd, 1980.

Sućeska, M.: Eksplozije i eksplozivi, knjiga, Brodarski Institut, Zagreb, 2001.

Todorovski, Đ.: Skladištenje, čuvanje i održavanje ubojitih sredstava, uputa, MORH, Zagreb, 1994.

Todorovski, Đ.: Skladištenje, čuvanje i održavanje ubojitih sredstava, priručnik, MORH, Zagreb, 1998.

Todorovski, Đ.: Minsko-eksplozivna sredstva (MES), tehnički priručnik, MORH, Zagreb, 2010.

Todorovski, Đ.: Zrakoplovne bombe $i$ upaljači, tehnički priručnik, MORH, Zagreb, 2014.

Vulić, S.: Održavanje municije i minsko eksplozivnih sredstava, knjiga, CVTŠ KoV, Zagreb, 1985. 


\section{SAFE DESTRUCTION OF MILITARY} EXPLOSIVE DEVICES

SUMMARY: Military explosive devices (infantry, artillery and rocket munitions, anti-personnel, anti-tank and mortar shells, aviation and navy ammunition, explosives, bombs, etc.) are objects filled with explosive substances (initial and high explosives, propellants, pyrotechnic mixtures) classified in Class 1 of dangerous substances, subclasses 1.1 to 1.6. In view of and taking into account the structural, chemical, physical and other characteristics of explosive devices, all prescribed safety and protection measures must be observed, covering the time of their production, storage, preservation, maintenance, handling, transporting, use and destruction.

Military explosive devices that, for whatever reason, cannot be of further use and are therefore written off as run out, defective, dangerous to human life and the environment or deemed unnecessary are destroyed, or brought to a state of permanent and total safety to human life and the environment. Also destroyed are explosive materials which failed to explode after use, as well as explosives found during demining of minefields after war. The destruction procedure is to be carried out in the prescribed manner with all measures of safety and protection to employees, other participants and the environment.

Key words: military explosive devices, explosive substances, demining, destruction

Professional paper Received: 2016-04-07

Accepted: 2016-08-29 